\title{
Life-history traits of Farlowella hahni (Siluriformes, Loricariidae) in streams of the Ivinhema River Basin, Upper Paraná Basin
}

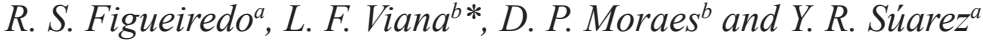 \\ aLaboratório de Ecologia, Centro de Estudos em Recursos Naturais - CERNA, Universidade Estadual de Mato Grosso do \\ Sul - UEMS, Rodovia Dourados/Itahum, Km 12, CEP 79804-970, Dourados, MS, Brasil \\ bPrograma de Pós-graduação em Recursos Naturais, Universidade Estadual de Mato Grosso do Sul - UEMS, \\ Rodovia Dourados/Itahum, Km 12, CEP 79804-970, Dourados, MS, Brasil \\ *e-mail: lucilenefinoto@hotmail.com
}

Received: June 6, 2017 -Accepted: October 16, 2017 - Distributed: May 31, 2019

(With 5 figures)

\begin{abstract}
Brazilian laws allow the catch of some species as ornamental fish; however, in the absence of biological information, such catch can threaten species conservation. Therefore, this study aimed to offer population and reproductive information about Farlowella hahni in streams of the Ivinhema River Basin, Upper Paraná Basin. To accomplish this, a total of $165 \mathrm{~F}$. hahni individuals were analyzed, including 109 females and 48 males, resulting in an important sex ratio difference from 1:1 $\left(\chi^{2}=19.97 ; p<0.001\right)$, indicating a predominance of females throughout the year. Females reach higher standard length than males. Males presented isometric Length-Weight Relationships, while females have positive allometric growth. Gonadosomatic index presented higher values from October through December. The mean fecundity was $100.3 \pm 36.4$ of vitellogenic oocytes and was positively correlated with standard length $(\mathrm{r}=0.51 ; \mathrm{p}=0.01)$. The data presented herein are the first for this species and suggest a need to carefully manage the F. hahni population, considering its low abundance and fecundity.
\end{abstract}

Keywords: Neotropical fish, reproduction, population structure.

\section{Traços de história de vida de Farlowella hahni (Siluriformes, Loricariidae) em riachos da Bacia do rio Ivinhema, Bacia do alto Paraná}

\begin{abstract}
Resumo
As leis brasileiras permitem a captura de algumas espécies de peixes como ornamentais, no entanto, a ausência de informações biológicas pode tornar esta captura uma ameaça para a conservação destas espécies. Este estudo teve como objetivo oferecer informações populacionais e reprodutivas sobre Farlowella hahni em riachos da Bacia do rio Ivinhema, bacia do Alto Paraná. Um total de 165 indivíduos de F. hahni foi analisado, sendo 109 fêmeas e 48 machos. A proporção de sexo foi diferente de 1:1 $(\chi 2=19,97 ; \mathrm{p}<0,001)$, com predominância de fêmeas ao longo do ano. As fêmeas atingiram maior comprimento padrão do que os machos. Os machos apresentaram crescimento isométrico e as fêmeas crescimento alométrico positivo. O índice gonadossomático apresentou maiores valores de Outubro a Dezembro. A fecundidade média foi de 100,3 $\pm 36,4$ de ovócitos vitelogênicos e foi correlacionada positivamente com o comprimento padrão $(\mathrm{r}=0,51 ; \mathrm{p}=0,01)$. Os dados apresentados são os primeiros para essa espécie e sugerem a necessidade de cuidados no manejo da população de $F$. hahni considerando baixa abundância e fecundidade.
\end{abstract}

Palavras-chave: peixes Neotropical, reprodução, estrutura populacional.

\section{Introduction}

Armored catfish are a highly diverse group. However, despite a growing number of taxonomic studies on this group in the Neotropical region (Albert and Reis, 2011), few ecological aspects of Neotropical species are known. The higher taxonomic diversity of this group is reflected in its morphology (Lujan et al., 2012) and habitat. In particular, streams are inhabited primarily by small-sized species that present little, or no, commercial value and have restricted distribution. They are largely dependent on riparian vegetation (Castro and Menezes, 1998). The Upper Paraná Basin provides primary habitat for this $F$. hahni, but it is also the region with highest human density in Brazil. Consequently, we see growing deforestation, even in riparian forest (Súarez et al., 2011).

Stream fishes are highly susceptible to unpredictable hydrological variations (Buckup, 1999; Lytle and Poff, 
2004). While little is known about their ecology (Wootton, 1992; Winemiller et al., 2008), Life-history traits and adjustment to environmental conditions have received more attention in the last few years (Baumgartner et al., 2008; Reynalte-Tataje et al., 2012; Silva et al., 2017).

Studies about the life-history of Loricariidae have focused on larger species, such as Hypostomus (Duarte and Araújo, 2002; Gomes et al., 2015; Cook-Hildreth et al., 2016), or relatively higher representatives of its assemblages, such as Loricariichthys platymetopon (Bailly et al., 2011). Still, little is known about small Loricariidae, which, from an ecological perspective, occur in relatively low abundance. Consequently, we need to know more about the life-history of Farlowella species in order to understand population structure and reproductive success, allowing us to, in turn, evaluate their conservation status and formulate appropriate management strategies (Giarrizzo et al., 2011; Dieb-Magalhães et al., 2015).

Species of Farlowella, which are commonly found in association with trunks in the river, are traditionally used as ornamental fish because of their beauty and exotic form, exhibiting a sticklike body and pronounced rostrum. Their preference for more complex habitats (Willis et al., 2005) appears to be a strategy designed to minimize predator encounter rates and maximize feeding. Farlowella hahni fishes occur in the Ivinhema River Basin, but in low abundance, and they mainly occur in association with riffle habitats, which lie below grassy vegetation in marginal mid to lower portions of the basin. Farlowella amazona is listed by the Brazilian Institute of Environment and Renewable Natural Resources (Brasil, 2012) as an ornamental fish with catch in the environment, recently, in Upper Paraná basin this species are renamed to F hahni (Ota et al., 2018). Nonetheless, no reproductive or population data are available to inform adequate management of this species.

Therefore, this study aimed to describe such life-history traits as length-weight relationship, seasonality in sex-ratio, reproductive activity, fecundity, size at first sexual maturation and spawn type for Farlowella hahni in streams of the Ivinhema River Basin, Upper Paraná Basin, Brazil.

\section{Material and Methods}

\subsection{Study area}

The Ivinhema River Basin is one of the main tributaries of the western part of the Paraná River located in Mato Grosso do Sul State, Brazil (Figure 1). This river basin is approximately $600 \mathrm{~km}$ long and covers $45,000 \mathrm{~km}^{2}$. It is one of the few remaining segments with lotic characteristics in the Upper Paraná Basin without influence of damming (Súarez et al., 2011; Ferreira and Súarez, 2015). Highest
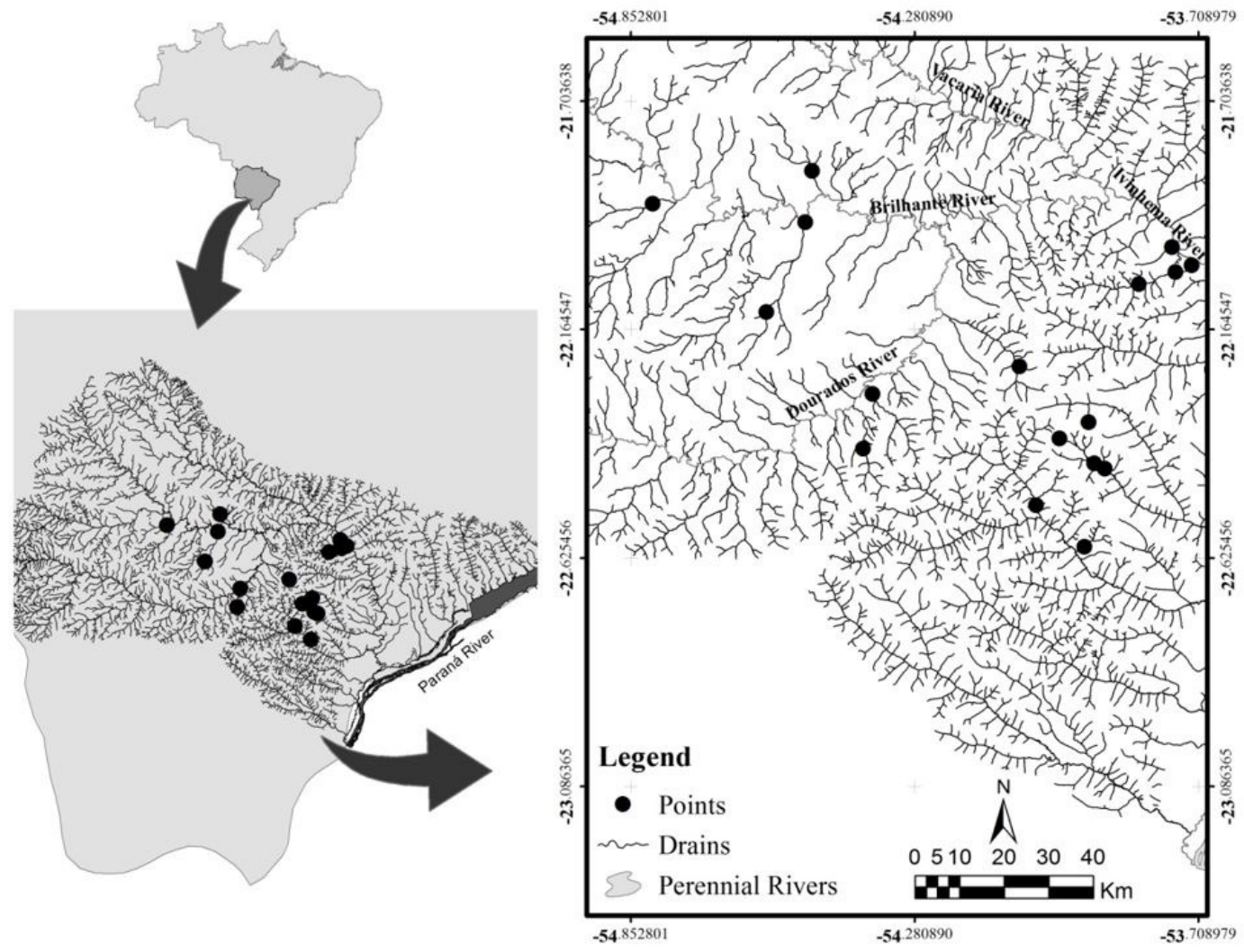

Figure 1. Study area and sampled streams in the Ivinhema River Basin, Upper Paraná Basin, Brazil. 
rainfall occurs from October to March in a Dourados subbasin region (Arai et al., 2010).

Compared to São Paulo and Paraná State, this section of the Upper Paraná River in Mato Grosso do Sul State is characterized by lower human density, although the region is impacted by agriculture and livestock. Still, the absence of larger dams and a larger floodplain portion in the lower portion allow for the maintenance of diversified ichthyofauna (Thomaz et al., 2007; Petsch et al., 2013), while also acting as an important environment for larger species to complete their life cycles (Santana and Minte-Vera, 2017).

\subsection{Data sampling}

Sampling was performed between 2001 and 2016, a total of 230 stream stretches distributed along the entire Ivinhema River. The studied species occurred in 17 sampled sites. The samples were taken during daylight with a rectangular sieve measuring $1.2 \times 0.8 \mathrm{~m}$ ( $2 \mathrm{~mm}$ mesh size) at each site, with approximately $100-\mathrm{m}$ long hauls. Specimens were fixed in $10 \%$ formalin and preserved in $70 \%$ ethanol for subsequent identification. A voucher specimen was deposited at the Fish Museum of the Universidade Estadual de Maringá (NUP\#9396). The study was conducted according to a protocol approved by the Ethics Committee of the Universidade Estadual de Mato Grosso do Sul (\#010/2014), and samples were authorized by SISBIO (\#13458-1).

In the laboratory, fish were identified according to Graça and Pavanelli (2007), and their standard length (mm), total weight (g), sex, maturation stage and gonad weight (g) were obtained. Individuals were classified as juveniles (immature) and adults (in maturation, mature, spent or at rest). For 23 mature females, all oocytes were counted and measured to determine fecundity and spawn type.

\subsection{Data analysis}

The differences in sex ratio for the whole period and the quarterly variation were quantified using the $\chi^{2}$ test, with the use of Yates correction for the first case.

Length/Weight relationship (LWR) were estimated according to the following equation: Total Weight $(\log )=a^{*}$ Length Standard $(\log ) * b$, where: $a=$ constant, and $b=$ allometric coefficient of growth (Ricker, 1973) estimated by linear regression (Froese, 2006). The degree of association between TW and LS was calculated by the adjusted determination coefficient $\left(\mathrm{r}^{2}\right)$. The confidence interval $( \pm 0.95 ; \alpha=0.05)$ of parameters a and $b$ were also estimated.

Quarterly variation in gonadosomatic index (GSI) was quantified through a Kruskal-Wallis analysis because homogeneity of variances and normality were not detected. The influence of female size on total fecundity was estimated using the Spearman correlation. The size of oocytes in mature females was measured by optical stereomicroscopy, and frequency distribution was used to determine total or split spawning.

The size at first sexual maturation was estimated for males and females using a logistic regression, and then the variation in the relationship between mature (1) and immature individuals $(0)$ was modeled as a function of fish size.

Absolute fecundity was estimated based on the total number of vitellogenic oocytes of ten mature females, whereas relative fecundity was determined by the number of vitellogenic oocytes per milligram of body weight for these same females (Arantes et al., 2013; Suzuki et al., 2000). For bulky ovaries, only a subsample was used, and the fecundity was estimated by the simple rule of three based on the assumption that the subsample contains the number of counted oocytes proportional to weight of this subsample relative to full ovarian weight. Relative fecundity was obtained from the number of mature oocytes per milligram of the total weight of females. Values for absolute fecundity, relative fecundity, and mean number of mature oocytes are presented.

Correlations between fecundity and standard length were tested using Spearman correlation rank coefficient in order to quantify variation in fecundity according to female size. Absolute fecundity was estimated from the total number of mature oocytes, and relative fecundity was determined by the ratio between the number of mature oocytes and total female weight.

Spawning type was determined by analysis of the relative frequencies of diameter classes of oocytes in ten mature females. Diameters of one hundred and fifty randomly chosen oocytes were measured using a magnifying glass with an ocular micrometer. The measurements were then converted into millimeter and used to obtain occurrence frequencies for oocyte diameters, which were then used to infer spawning type. Hatching mode was evaluated using histograms of the frequency distribution of oocyte diameters (Vazzoler, 1996). Observation of the most advanced mode of hatching, along with the position of the ovaries, indicated developmental oocytary phases, which permitted the inference of spawning type.

All statistical analyses were performed using the platform R (R Development Core Team, 2017). For all statistical tests, a significance level of $\mathrm{p}<0.05$ was adopted.

\section{Results}

A total of 165 individuals of $F$. hahni were analyzed, including 109 females, 48 males and 8 individuals of undetermined sex. The sex ratio differed from 1:1 $\left(\chi^{2}=19.97 ; \mathrm{df}=1 ; \mathrm{p}<0.001\right)$, indicating the predominance of females throughout the year. The standard length ranged from 33 to $175 \mathrm{~mm}$; males ranged from 58 to $159 \mathrm{~mm}$ (median=108.9 mm) and females from 51 to $175 \mathrm{~mm}$ (median=118.7 mm) (Figure 2).

Males showed isometric growth according to LWR: Total weight $=0.00000084 *$ Standard length ${ }^{3.10}$ with confidence Interval for a $\left(\mathrm{CI}_{\alpha 0.05}=0.00000048\right.$ to 0.0000014$)$ and for angular coefficient $\left(\mathrm{CI}_{\alpha 0.05}=2.98\right.$ to 3.22$)\left(\mathrm{r}^{2}=0.98 ; \mathrm{F}=2797\right.$; $\mathrm{p}<0.001)$. Females showed positive allometric growth according to LWR: Total weight $=0.00000040 *$ Standard length ${ }^{3.27}$ with confidence Interval for a $\left(\mathrm{CI}_{\alpha 0.05}=0.00000024\right.$ to 0.00000068$)$ 


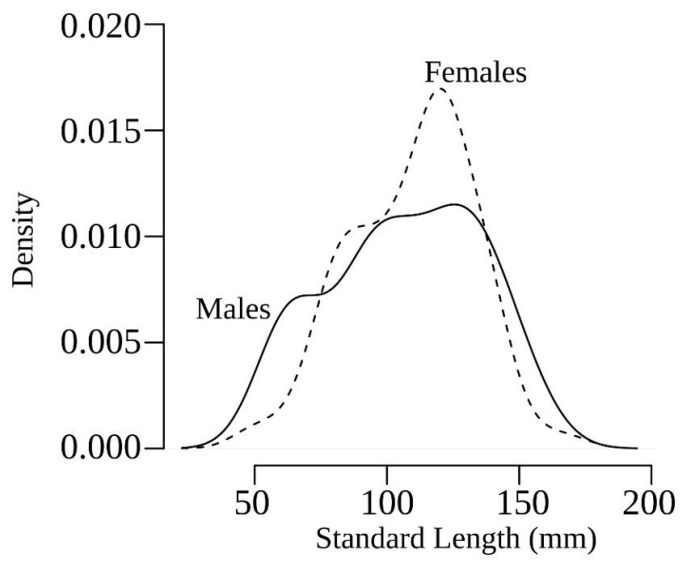

Figure 2. Density plots of standard length ( $\mathrm{mm}$ ) for females and males of Farlowella hahni in streams of the Ivinhema River Basin, Upper Paraná River, from 2001 to 2016. and for angular coefficient $\left(\mathrm{CI}_{\alpha 0.05}=3.17\right.$ to 3.38$)\left(\mathrm{r}^{2}=0.97\right.$; $\mathrm{F}=3514 ; \mathrm{p}<0.001)$. This finding of isometric growth of males and positive allometric growth for females is the first estimate reported for F. hahni (Figure 3).

A significant seasonal difference was observed in the gonadosomatic index (Kruskal-Wallis $\mathrm{H}=10.70$; $\mathrm{p}=0.013$ ), and the highest GSI values were observed from October through December (Figure 4A). Size at first sexual maturation for females was estimated as $100.4 \mathrm{~mm}\left(\mathrm{CI}_{\alpha 0.05}=94.7\right.$ to $106.1 \mathrm{~mm})$. The size at which $100 \%$ of females were considered mature was $166.1 \mathrm{~mm}$ with CI varying from 142.9 to $189.3 \mathrm{~mm}$ (Figure 4B).

Absolute fecundity varied from 55 to 194 vitellogenic oocytes (mean $=100.3 \pm 36.4$ ) and was positively correlated with standard length (Spearman $\mathrm{r}=0.51 ; \mathrm{p}=0.01$ ) (Figure 5A). Oocyte diameters showed two peaks, with the first representing reserve oocytes and the second varying from 1.3 to $1.6 \mathrm{~mm}$ as mature oocytes, ready for spawning (Figure 5B).
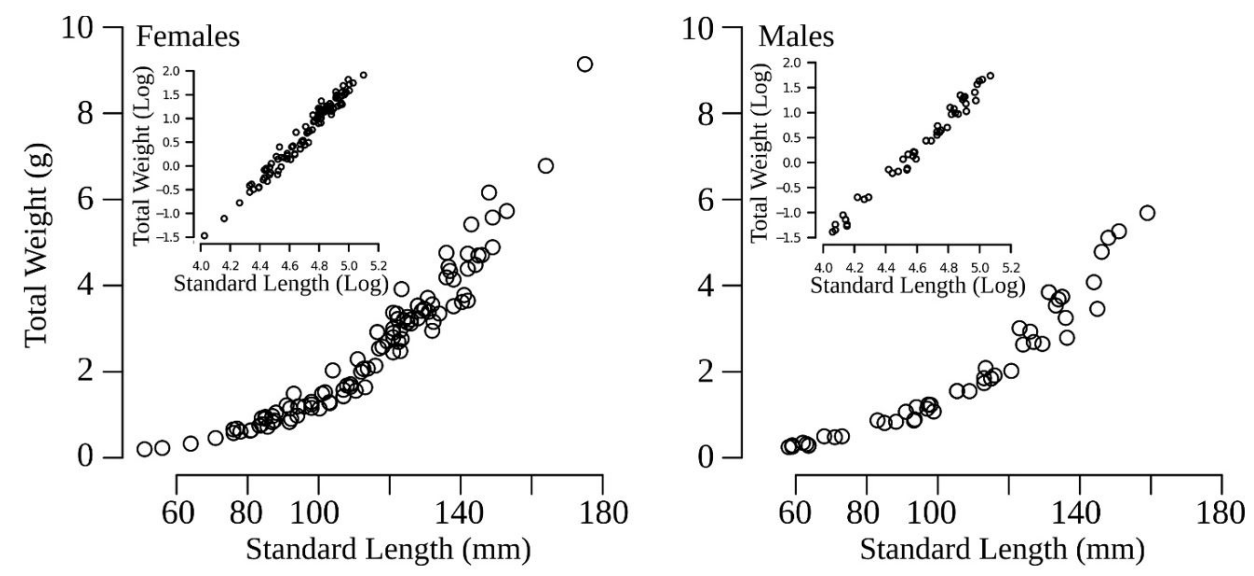

Figure 3. LWR for females and males of Farlowella hahni in streams of Ivinhema River Basin, Upper Paraná River, from 2001 to 2016.
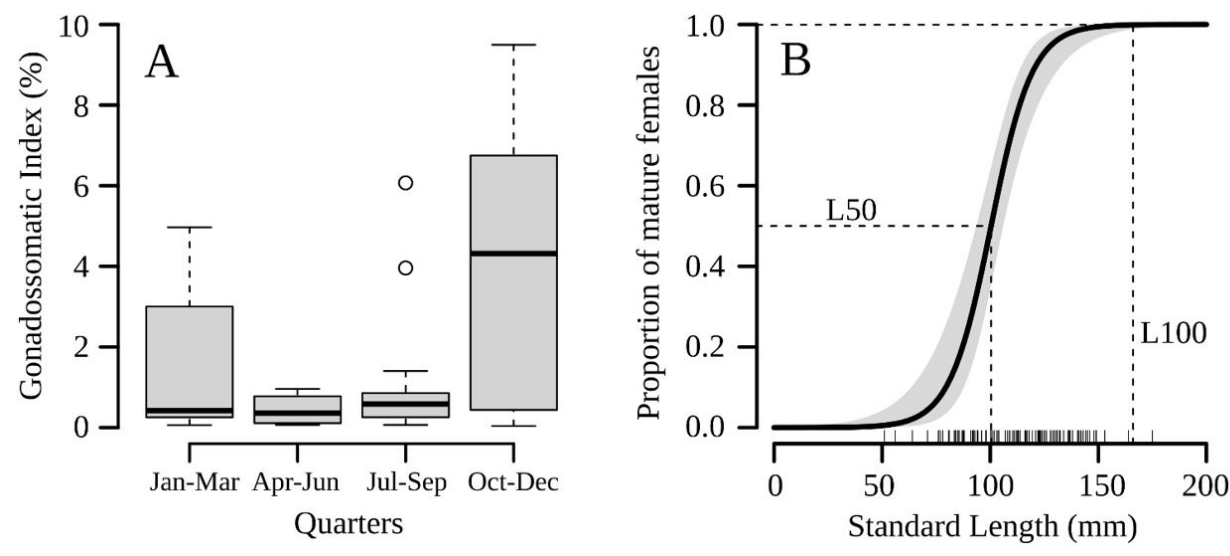

Figure 4. (A) Variation in mean gonadosomatic index ( \pm standard deviation) and (B) proportion of mature females along a standard length (mm) gradient for Farlowella hahni in streams of the Ivinhema River Basin, Upper Paraná River, from 2001 to 2016. 

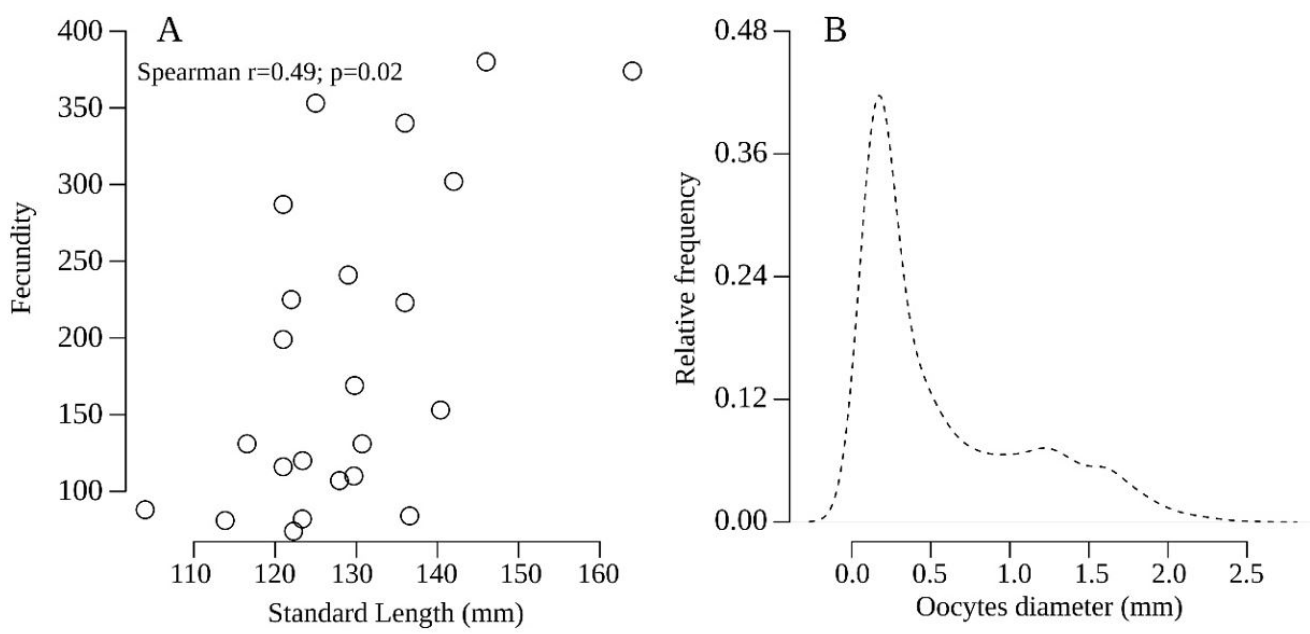

Figure 5. (A) Relationship between fecundity and female standard length and (B) density graph of oocyte diameter for Farlowella hahni in streams of the Ivinhema River Basin, Upper Paraná River, from 2001 to 2016.

\section{Discussion}

The sex ratio difference from 1:1 is considered a disadvantage in sexual competition, with the members of the predominant sex transmitting their genes with lower frequency to the next generation. However, it is expected that populations with a need for rapid growth will have a higher proportion of females, e.g., prey species or populations in the process of colonization. The predominance of females has been reported for other small loricariid species in the Neotropical region, e.g., Neoplecostomus microps (Levitan, 2005; Braga et al., 2008), Pareiorhina rudolphi (Braga et al., 2009), Loricariichthys castaneus (Gomes et al., 2011) and Loricarichthys platymetopon (Suzuki et al., 2000). For Farlowella species, only $F$. vittata has available data about sex ratio in the Güejar River (Colombia), and this species did not present differences in sex-ratio (García-Alzate et al., 2012).

Current hypotheses used to explain differences in sex ratio are usually focused on differential survival rates between sexes, in predation rates or spatial segregation (Dala-Corte and Azevedo, 2010; Cetra et al., 2011; Tondato et al., 2012). We observed that juvenile $F$. hahni mainly occurred in streams close to rivers or in larger rivers, probably in response to higher hydrological unpredictability of streams (Súarez et al., 2011) and water velocity. Variation in sex ratio could be explained by the lower survival of juveniles, while the predominance of females could be viewed as a strategy for population maintenance, or the inability of males to survive in streams with higher current velocities, though not mutually exclusive. Considering the absence of data for other Farlowella species and the fact of our results are strikingly different from those reported to $F$. vittata, are need more data for different populations of $F$. hahni or other species to better understand if a variation in the sex ratio pattern can be identified.
The Length/Weight relationship (LWR) allows us to understand how populations, or sexes, allocate resources to somatic growth. Environmental influences on fish growth also can be viewed using LWR in that populations with better resource availability should show higher somatic growth. The differences between sexes in our study could be attributed to 1) the superior efficiency of females in obtaining feeding resources, or, though not mutually exclusive, 2) males being more affected by predation or environmental pressures. Since females reach higher standard length and need biomass accumulation to reproduce, the difference in angular coefficient of LWR can be a strategy to store energy against future reproduction, a theory raised by other studies (Marcucci et al., 2005).

The Gonadosomatic index presented higher values from October to December, suggesting higher reproductive activity in this period which coincides with increased temperatures and more rainfall in the sampled region, suggesting that these environmental descriptors can act as triggers to spawn. A similar result was observed for F. vittata (García-Alzate et al., 2012), which presented a similar reproductive response to environmental cues. Some studies suggested that higher pluviosity can decrease predation and intraspecific competition for food and space (Stoumboudi et al., 1993; García-Alzate et al., 2012; Freitas et al., 2015). However, we cannot exclude the positive effect of increase in net productivity offering better conditions for ovarian development and survival of juveniles, perhaps also associated with a possible reduction in predation by habitat expansion in small flooding events in lower portions of the streams. Other studies reported similar findings, thus generating the idea that fish fitness is associated with the commencement of greater rainfall and rise in temperature (Trajano, 1997; Ramos and Konrad, 1999), in agreement with our data. 
At first maturation, we estimated that $F$. hahni reached a size of $100.4 \mathrm{~mm}$, smaller than that estimated for $F$. vittata (122 mm) (García-Alzate et al., 2012). Considering that F. vittata reached $190.4 \mathrm{~mm}$ of standard length, while $F$. hahni reached $175 \mathrm{~mm}$ relative to differences in water temperature between sampled regions ( $F$. vittata: mean temperature $=26^{\circ} \mathrm{C} ; \mathrm{F}$. hahni: mean temperature $=24.7^{\circ} \mathrm{C}$ ), the analyzed species reach first maturation at $64 \%$ and $57.4 \%$ of maximum registered size, respectively. This life-history trait is an important descriptor of fish biology and is a fundamental tradeoff against the exigencies of fish growth, survival and fitness (Braga et al., 2008; Dieb-Magalhães et al., 2015).

The positive relationship between fecundity and female length is common (Vasconcelos et al., 2011); on the other hand, the lower fecundity observed for $F$. hahni is consistent with that observed for $F$. vittata (mean=46 oocytes). The higher mean values for $F$. hahni suggest that this could be a characteristic trait of this fish group. In contrast, the diameter of $F$. vittata vitellogenic oocytes is similar to that of $F$. hahni $(F$. vittata $=1.4 \mathrm{~mm}$; F. hahni=1.3-1.6 mm), suggesting that this pattern is common to this species group and the possible result of investment in parental care (Gross and Sargent, 1985), thus explaining the lower fecundity and higher oocyte diameter (Mazzoni and Caramaschi, 1995; Dala-Corte and Azevedo, 2010). This could mean that the greater number of oocytes might compensate for the lower fecundity, increasing, in turn, the probability of survival of juveniles in a phase without the use of exogenous energy (Braga et al., 2008).

Spawn type was considered total based on oocyte diameter of two clear groups, despite the smaller variation in vitellogenic oocyte diameter (1.3 to $1.6 \mathrm{~mm}$ ). Total spawn appeared to be associated with reproductive period and was concentrated from late spring to summer. The occurrence of juveniles near larger streams and rivers implies a relationship between reproductive traits and hydrological characteristics of the sampled environment. This hypothesis corroborates the results of Espírito-Santo et al. (2013) who found a strong relationship between hydrological gradient and reproductive traits for species with large eggs spawning seasonally and influenced by hydrology.

In conclusion, these findings represent the first reported data about population structure and reproductive biology of Farlowella hahni, suggesting that females are larger, more abundant and present higher allocation of resources in weight compared to males. Reproduction is concentrated from late spring to summer, and fecundity is low, but with a greater number of oocytes and total spawn. These results tell us that exploitation of this species should be understood in terms of its biological characteristics. More specifically, in the Ivinhema River Basin, given the low occurrence rate of $10 \%$ of sampled site and associated low fecundity, more prudent conservation steps toward management of this species are recommended.

\section{Acknowledgements}

The authors acknowledge the financial support of FUNDECT, CNPq and CAPES. We are grateful to Lilian Paula Vasconcelos, Maiane J. Pereira, Marcelo M. Souza and Karina K. Tondato for help in the fieldwork. Y. R. Súarez is supported by productivity grants from $\mathrm{CNPq}$.

\section{References}

ALBERT, J.S. and REIS, R.E., 2011. Major biogeographic and phylogenetic patterns. In: J. ALBERT, ed. Historical biogeography of neotropical freshwater fishes. Berkeley: University of California Press. http://dx.doi.org/10.1525/california/9780520268685.001.0001. PMid:15003161.

ARAI, F.K., GONÇALVES, G.G.G., PEREIRA, S.B., COMUNELLO, É., VITORINO, A.C.T. and DANIEL, O., 2010. Espacialização da precipitação e erosividade na Bacia Hidrográfica do Rio Dourados - MS. Engenharia Agrícola, vol. 30, no. 5, pp. 922-931. http://dx.doi.org/10.1590/S0100-69162010000500014.

ARANTES, F.P., SATO, Y., SAMPAIO, E.V., RIZZO, E. and BAZZOLI, N., 2013. Spawning induction and fecundity of commercial native fish species from the São Francisco River basin, Brazil, under hatchery conditions. Agricultural Sciences, vol. 4, no. 8, pp. 382-388. http://dx.doi.org/10.4236/as.2013.48055.

BAILLY, D., BATISTA-SILVA, V.F., ABELHA, M.C.F., KASHIWAQUI, E.A.L., FERNANDES, C.A. and CARVALHO, E.D., 2011. Relative abundance and reproductive tactics of a Loricariidae species at Saraiva Lagoon, Ilha Grande National Park, MS-PR, Brazil. Biota Neotropica, vol. 11, no. 3, pp. 171-178. http://dx.doi.org/10.1590/S1676-06032011000300014.

BAUMGARTNER, G., NAKATANI, K., GOMES, L.C., BIALETZKI, A., SANCHES, P.V. and MAKRAKIS, M.C., 2008. Fish larvae from the upper Paraná River: do abiotic factors affect larval density? Neotropical Ichthyology, vol. 6, no. 4, pp. 551-558. http://dx.doi.org/10.1590/S1679-62252008000400002.

BRAGA, F.M., GOMIERO, L.M. and SOUZA, U.P., 2008. Aspectos da reprodução e alimentação de Neoplecostomus microps (Loricariidae, Neoplecostominae) na microbacia do Ribeirão Grande, serra da Mantiqueira oriental (Estado de São Paulo). Acta Scientiarum. Biological Sciences, vol. 30, no. 4, pp. 455-463. http://dx.doi.org/10.4025/actascibiolsci.v30i4.301.

BRAGA, F.M.S., GOMIERO, L.M. and SOUZA, U.P., 2009. Biologia populacional de Pareiorhina rudolphi (Loricariidae, Hypostominae) na microbacia do Ribeirão Grande, serra da Mantiqueira oriental, Estado de São Paulo. Acta Scientiarum, vol. 31, no. 1, pp. 79-88.

BRASIL. Instituto Brasileiro do Meio Ambiente e dos Recursos Naturais Renováveis - IBAMA, 2012 [viewed 30 March 2017]. Instrução Normativa Interministerial $n^{\circ} 1$, de 3 de janeiro de 2012. Estabelece normas, critérios e padrões para a explotação de peixes nativos ou exóticos de águas continentais com finalidade ornamental ou de aquariofilia [online]. Diário Oficial da República Federativa do Brasil, Brasilia, 4 janeiro. Available from: http://www.icmbio.gov.br/cepsul/images/stories/legislacao/ Instrucao_normativa/2012/in_inter_mpa_mma_01_2012 exploracaopeixesnativosexoticosaguascontinentais.pdf

BUCKUP, P.A., 1999. Sistemática e biogeografia de peixes de riachos. Oecologia Australis, vol. 6, no. 1, pp. 91-138. http:// dx.doi.org/10.4257/oeco.1999.0601.03. 
CASTRO, R.M.C. and MENEZES, N.A., 1998. Estudo diagnóstico da diversidade de peixes do Estado de São Paulo. In: R.M.C. CASTRO, ed. Biodiversidade do Estado de São Paulo, Brasil: sintese do conhecimento ao final do século XX. São Paulo: WinnerGraph, vol. 6, pp. 1-13.

CETRA, M., RONDINELI, G.R. and SOUZA, U.P., 2011. Compartilhamento de recursos por duas espécies de peixes nectobentônicas de riachos na bacia do rio Cachoeira (BA). Biota Neotropica, vol. 11, no. 2, pp. 87-95. http://dx.doi.org/10.1590/ S1676-06032011000200010.

COOK-HILDRETH, L., BONNER, T. and HUFFMAN, D., 2016. Female reproductive biology of an exotic suckermouth armored catfish (Loricariidae) in the San Marcos River, Hays Co., Texas, with observations on environmental triggers. BioInvasions Records, vol. 5, no. 3, pp. 173-183. http://dx.doi.org/10.3391/ bir.2016.5.3.09.

DALA-CORTE, R.B. and AZEVEDO, M.A., 2010. Biologia reprodutiva de Astyanax henseli (Teleostei, Characidae) do curso superior do Rio dos Sinos, RS, Brasil. Iheringia. Série Zoologia, vol. 100 , no. 3, pp. 259-266. http://dx.doi.org/10.1590/S007347212010000300012

DIEB-MAGALHÃES, L., FLORENTINO, A.C. and SOARES, M.G.M., 2015. Length-weight relationships and length at first maturity for nine fish species of floodplain lakes in Central Amazon (Amazon Basin, Brazil). Journal of Applied Ichthyology, vol. 31, no. 6, pp. 1182-1184. http://dx.doi.org/10.1111/jai.12919.

DUARTE, S. and ARAÚJO, F.G., 2002. Fecundity of the Hypostomus affinis (Siluriformes, Loricariidae) in the Lajes Reservoir, Rio de Janeiro, Brazil. Revista de Biología Tropical, vol. 50, no. 1, pp. 193-197. PMid:12298245.

ESPÍRITO-SANTO, H.M.V., RODRÍGUEZ, M.A. and ZUANON, J., 2013. Reproductive strategies of Amazonian stream fishes and their fine-scale use of habitat are ordered along a hydrological gradient. Freshwater Biology, vol. 58, no. 12, pp. 2494-2504. http://dx.doi.org/10.1111/fwb.12225.

FERREIRA, F.S. and SÚAREZ, Y.R., 2015. Estrutura populacional e aspectos reprodutivos de Corydoras aeneus (Siluriformes, Callichthyidae) em riachos da bacia do rio Ivinhema, Alto rio Paraná. Iheringia. Série Zoologia, vol. 105, no. 4, pp. 474-483. http://dx.doi.org/10.1590/1678-476620151054474483.

FREITAS, T.M.S., PRUDENTE, B.S., OLIVEIRA, V.A., OLIVEIRA, M.N.C., PRATA, E.G., LEÃO, H. and MONTAG, L.F.A., 2015. Influence of the flood pulse on the reproduction of Tocantinsia piresi (Miranda Ribeiro) and Auchenipterus nuchalis (Spix \& Agassiz) (Auchenipteridae) of the middle Xingu River, Brazil. Brazilian Journal of Biology $=$ Revista Brasileira de Biologia, vol. 75, no. 3, suppl. 1, pp. 158-167. http://dx.doi. org/10.1590/1519-6984.00114BM. PMid:26691087.

FROESE, R., 2006. Cube law, condition factor and weight-length relationships: history, meta-analysis and recommendations. Journal of Applied Ichthyology, vol. 22, no. 4, pp. 24-253. http://dx.doi. org/10.1111/j.1439-0426.2006.00805.x.

GARCÍA-ALZATE, C.A., ROMÁN-VALENCIA, C. and BARRERO, A.M., 2012. Food and reproductive biology of Farlowella vittata (Siluriformes: Loricariidae) in Güejar River Basin, Orinoco, Colombia. Revista de Biología Tropical, vol. 60, no. 4, pp. 1873-1888. http://dx.doi.org/10.15517/rbt.v60i4.2187. PMid:23342535.

GIARRIZZO, T., BASTOS, D. and ANDRADE, M., 2011. Lengthweight relationships for selected fish species of Rio Trombetas
Biological Reserve: a reference study for the Amazonian basin. Journal of Applied Ichthyology, vol. 27, no. 6, pp. 1422-1424. http://dx.doi.org/10.1111/j.1439-0426.2011.01820.x.

GOMES, I.D., ARAÚJO, F.G., NASCIMENTO, A.A. and SALES, A., 2015. Equilibrium reproductive strategy of the armored catfish Hypostomus auroguttatus (Siluriformes, Loricariidae) in a tropical river in Southeastern Brazil. Environmental Biology of Fishes, vol. 98, no. 1, pp. 249-260. http://dx.doi.org/10.1007/ s10641-014-0256-5.

GOMES, I.D., ARAÚJO, F.G., UEHARA, W. and SALES, A., 2011. Reproductive biology of the armoured catfish Loricariichthys castaneus (Castelnau, 1855) in Lajes reservoir, southeastern Brazil. Journal of Applied Ichthyology, vol. 27, no. 6, pp. 1322-1331. http://dx.doi.org/10.1111/j.1439-0426.2011.01874.x.

GRAÇA, W.J. and PAVANELLI, C.S., 2007. Peixes da planície de inundação do Alto Rio Paraná e áreas adjacentes. Maringá: EDUEM, $241 \mathrm{p}$

GROSS, M.R. and SARGENT, R.C., 1985. The evolution of male and female parental care in fishes. American Zoologist, vol. 25, no. 3, pp. 807-822. http://dx.doi.org/10.1093/icb/25.3.807.

LEVITAN, D.R., 2005. Sex-specific spawning behavior and its consequences in an external fertilizer. American Naturalist, vol. 165 , no. 6, pp. 682-694. http://dx.doi.org/10.1086/429733. PMid: 15937748

LUJAN, N.K., WINEMILLER, K.O. and ARMBRUSTER, J.W., 2012. Trophic diversity in the evolution and community assembly of loricariid catfishes. BMC Evolutionary Biology, vol. 12, no. 1, pp. 124. http://dx.doi.org/10.1186/1471-2148-12-124. PMid:22835218

LYTLE, D.A. and POFF, N.L., 2004. Adaptation to natural flow regimes. Trends in Ecology \& Evolution, vol. 19, no. 2, pp. 94-100. http://dx.doi.org/10.1016/j.tree.2003.10.002. PMid:16701235.

MARCUCCI, K.M.I., ORSI, M.L. and SHIBATTA, O.A., 2005. Abundância e aspectos reprodutivos de Loricariichthys platymetopon (Siluriformes, Loricariidae) em quatro trechos da represa Capivara, médio rio Paranapanema. Iheringia, Série Zoologia, vol. 95, no. 2, pp. 197-203. http://dx.doi.org/10.1590/ S0073-47212005000200010.

MAZZONI, R. and CARAMASCHI, E.P., 1995. Size structure, sex ratio and onset of sexual maturity of two species of Hypostomus. Journal of Fish Biology, vol. 47, no. 5, pp. 841-849. http://dx.doi. org/10.1111/j.1095-8649.1995.tb06006.x.

OTA, R.R., DEPRÁ, G.C., GRAÇA, W.J. and PAVANELLI, C.S., 2018. Peixes da planície de inundação do alto rio Paraná e áreas adjacentes: revised, annotated and updated. Neotropical Ichthyology, vol. 16, no. 2, pp. e170094. http://dx.doi. org/10.1590/1982-0224-20170094.

PETSCH, D.K., PINHA, G.D., RAGONHA, F.H. and TAKEDA, A.M., 2013. Influência dos fatores ambientais sobre a distribuição da comunidade de invertebrados bentônicos em canais de uma planície de inundação neotropomunidade de invertebrados bentônicos em canais secundários e principal de uma planície de inundação neotropical. Biotemas, vol. 26, no. 3, pp. 127-138. http://dx.doi.org/10.5007/2175-7925.2013v26n3p127.

R DEVELOPMENT CORE TEAM, 2017 [viewed 30 March 2017]. $R$ : a language and environment for statistical computing [online]. Vienna: R Foundation for Statistical Computing. Available from: https://www.R-project.org/ 
RAMOS, L.A. and KONRAD, H.G., 1999. Biologia reprodutiva de Hemiancistrus sp. (Osteichthyes, Loricariidae) do Rio dos Sinos, RS. Boletim do Instituto de Pesca, vol. 25, pp. 45-50.

REYNALTE-TATAJE, D.A., NUÑER, A.P.O., NUNES, M.C., GARCIA, V., LOPES, C.A. and ZANIBONI-FILHO, E., 2012. Spawning of migratory fish species between two reservoirs of the upper Uruguay River, Brazil. Neotropical Ichthyology, vol. 10, no. 4, pp. 829-835. http://dx.doi.org/10.1590/S167962252012000400016 .

RICKER, W.E., 1973. Russian-English dictionary for students of fisheries and aquatic biology. Ottawa: Fisheries Research Board of Canada, 148 p. Bulletin of the Fisheries research board of Canada.

SANTANA, H.S. and MINTE-VERA, C.V., 2017. Age and growth of Prochilodus lineatus in a spatially structured population: is there concordance between otoliths and scales? Environmental Biology of Fishes, vol. 100, no. 3, pp. 223-235. http://dx.doi. org/10.1007/s10641-017-0574-5.

SILVA, C.B., DIAS, J.D. and BIALETZKI, A., 2017. Fish larvae diversity in a conservation area of a neotropical floodplain: influence of temporal and spatial scales. Hydrobiologia, vol. 787, no. 1, pp. 141-152. http://dx.doi.org/10.1007/s10750-016-2953-x.

STOUMBOUDI, M.T., VILLWOCK, W., SELA, J. and ABRAHAM, M., 1993. Gonadosomatic index in Barbus longiceps, Capoeta damascina and their natural hybrid (Pisces, Cyprinidae), versus spermatozoan index in the parental males. Journal of Fish Biology, vol. 43, no. 6, pp. 865-875. http://dx.doi. org/10.1111/j.1095-8649.1993.tb01161.x.

SÚAREZ, Y.R., SOUZA, M.M., FERREIRA, F.S., PEREIRA, M.J., SILVA, E.A., XIMENES, L.Q.L., AZEVEDO, L.G., MARTINS, O.C. and LIMA JÚNIOR, S.E., 2011. Patterns of species richness and composition of fish assemblages in streams of the Ivinhema River basin, Upper Paraná River. Acta Limnologica Brasiliensia, vol. 23, no. 2, pp. 177-188. http://dx.doi.org/10.1590/ S2179-975X2011000200008.

SUZUKI, H.I., AGOSTINHO, A.A. and WINEMILLER, K.O., 2000. Relationship between oocyte morphology and reproductive strategy in loricariid catfishes of the Paraná River, Brazil. Journal of Fish Biology, vol. 57, no. 3, pp. 791-807. http:// dx.doi.org/10.1006/jfbi.2000.1352.

THOMAZ, S.M., BINI, L.M. and BOZELLI, R.L., 2007. Floods increase similarity among aquatic habitats in river-floodplain systems. Hydrobiologia, vol. 579, no. 1, pp. 1-13. http://dx.doi. org/10.1007/s10750-006-0285-y.

TONDATO, K.K., FIALHO, C.B. and SÚAREZ, Y.R., 2012. Traços de história de vida de Odontostilbe pequira (Steindachner, 1882) no pantanal de Porto Murtinho, Mato Grosso do Sul, Brasil. Oecologia Australis, vol. 16, no. 4, pp. 878-890. http://dx.doi. org/10.4257/oeco.2012.1604.11.

TRAJANO, E., 1997. Food and reproduction of Trichomycterus itacarambiensis, cave catfish from south-eastern Brazil. Journal of Fish Biology, vol. 51, no. 1, pp. 53-63. http://dx.doi. org/10.1111/j.1095-8649.1997.tb02513.x. PMid:9236088.

VASCONCELOS, L.P., SÚAREZ, Y.R. and LIMA-JUNIOR, S.E., 2011. Population aspects of Bryconamericus stramineus in streams of the upper Paraná River basin, Brazil. Biota Neotropica, vol. 11, no. 2, pp. 55-62. http://dx.doi.org/10.1590/ S1676-06032011000200006.

VAZZOLER, A.E.A.M., 1996. Biologia da reprodução de peixes teleósteos: teoria e prática. Maringá: EDUEM, 169 p.

WILLIS, S.C., WINEMILLER, K.O. and LOPEZ-FERNANDEZ, H., 2005. Habitat structural complexity and morphological diversity of fish assemblages in a Neotropical floodplain river. Oecologia, vol. 142, no. 2, pp. 284-295. http://dx.doi.org/10.1007/s00442004-1723-z. PMid:15655689.

WINEMILLER, K.O., AGOSTINHO, A.A. and CARAMASCHI, É.P., 2008. Fish ecology in stream tropical. In: D. DUDGEON, ed. Tropical streams ecology. San Diego: Academic Press, pp. 107-146. http://dx.doi.org/10.1016/B978-012088449-0.50007-8.

WOOTTON, R.J., 1992. Fish ecology. Netherlands: Springer, 212 p. http://dx.doi.org/10.1007/978-94-011-3832-1. 